\title{
DEVELOPMENT AND EXPERIMENTAL STUDY OF PHANTOMS FOR MAPPING SKIN CHROMOPHORES
}

\author{
A. Silapetere, I. Saknite, J. Spigulis \\ Biophotonics Laboratory \\ Institute of Atomic Physics and Spectroscopy, \\ University of Latvia, \\ 19 Raina Blvd., LV-1586, Riga, LATVIA \\ e-mail: arita.silapetere@gmail.com
}

\begin{abstract}
Skin chromophore phantoms are widely used for better understanding of the light interaction with tissue and for calibration of skin diagnostic imaging techniques. In this work, different phantoms were examined and compared in order to find biologically equivalent substances that are the most promising for this purpose. For mimicking the skin medium and layered structure, a fibrin matrix with epidermal and dermal cell inclusion was used. Synthesized bilirubin, red blood cells and nigrosin were taken as absorbers. For spectral analysis of the developed phantoms a computer-aided multispectral imaging system Nuance 2.4 (Cambridge Research \& Instrumentation, Inc., USA) was used. In this study, skin phantoms were created using such substances as bilirubin, melanin, haemoglobin and nigrosin.
\end{abstract}

Keywords: skin phantom, multi-spectral imaging, skin chromophore mapping, bilirubin, melanin, haemoglobin, nigrosin.

\section{INTRODUCTION}

Nowadays, light is used in various fields of health care - from neurosurgery to medical diagnostics. In this study, the domain of interest is the application of light in human skin diagnostics. Optical methods are widely used in medicine due to numerous advantages. The most important are the following: information about skin tissue can be obtained noninvasively and in real time; a low-cost technology; not affecting a patient's health in any known way [1]. Multi-dimensional pictures of skin are obtained by wide-range spectral imaging techniques, and using BeerLambert's law relative parameter values can be calculated [2]. In order to better understand the physiological properties of skin and to calibrate the spectral imaging devices, a human tissue phantom is necessary. Human tissue phantoms or so-called skin phantoms can be developed with known optical properties (absorbance and scattering). These properties should be comparable with those of living tissue and be stable in time, so that they are applicable as "golden standards".

Extensive studies have already been done for the purpose to develop skin phantoms (see e.g. [3-9]). In skin phantoms mostly water, agar, polyester, polyurethane, silicon, polydimethylsiloxane, fat and milk are used as matrix 
materials. Phantoms containing hydrogel are appropriate in laboratory studies for mimicking the biological properties. Polymaterials and silicones are desirable for routine calibration as they are stable in time. As scattering media, titanium oxide powder, aluminium oxide powder, and lipid-based emulsion are used. Diversified materials are employed as absorbers, e.g. molecular dyes, inks, cells, haemoglobin cells, coffee, nigrosin, etc. [3-9].

In the visible and near-infrared spectroscopy it is crucial for phantoms to mimic the layered structure and chemistry of the tissue. Biologically compatible structures are more suitable for these measurements than nonorganic polymers and silicones. The tissue engineering has developed to the point where biological structures can be created or grown in culture. Skin phantoms should have a layered structure in order to modulate the unique structure of human skin. For molecular imaging techniques, more suitable are skin phantoms having molecular properties similar to those of human skin. The phantoms simulating biological tissue have the potential to become the main calibration structures for molecular imaging systems [3].

In this study, a biologically compatible skin phantom has been created, with a fibrin matrix chosen as the main medium for the phantom. Such a matrix allows an easy inclusion of epidermal and dermal cells and chromophores (haemoglobin, bilirubin) to be used as absorbers. This makes possible accurate simulation of the layered structure and the chemistry of skin.

Biological phantoms have a variety of applications, e.g. performance comparison for different apparatus, quality control of skin diagnostic equipment and system testing [3].

When light interacts with human skin, some its portion is instantly reflected while some penetrates the skin where it undergoes multiple scattering, and some is absorbed and diffuse-reflected. By analyzing diffuse-reflected light it is possible to obtain information about absorption in the tissue. With this technique (illustrated in Fig.1 [10]) we consider scattering only as light transport and do not analyze it in more detail.

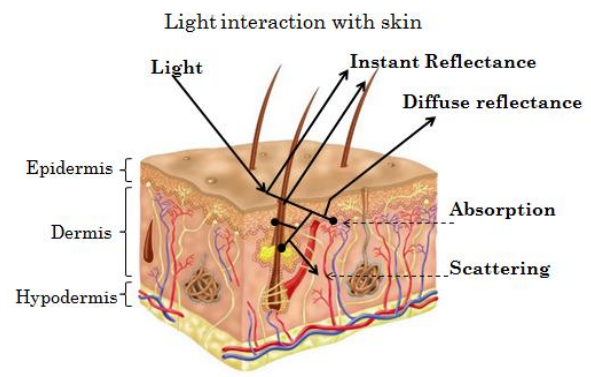

Fig.1. Light interaction with skin.

Skin is a heterogeneous multi-layered structure consisting of different absorbers. In the so-called therapeutic window $(600-1300 \mathrm{~nm})$ - the range in which water absorption is only minor - most of tissues, e.g. tryptophan, NADH, collagen, elastin, etc., are weak absorbers. In the spectral region of interest $(450-900 \mathrm{~nm})$ these tissues also have insignificant absorption properties; within this spectral range strong absorbers are haemoglobin, deoxyhaemoglobin, bilirubin and 
melanin. These are the chromophores of human skin that are responsible for the colour of skin and can give information about skin condition and human health as well [11].

Bilirubin is the breakdown product of haem degradation. Bilirubin is excreted in urine and bile; increased bilirubin concentration in these fluids may indicate health problems. Bilirubin concentration in skin is relatively low, increasing in bruises and being responsible for their yellow colour [12]. In Fig.2 the absorption spectrum of bilirubin is shown [13].

When human skin is exposed to UV light, melanocytes produce melanin. Melanin serves as a photoprotectant; this minimizes damage done to human body and skin by UV radiation. It is responsible for the skin tone - the higher melanin concentration in human skin, the darker is the tone. Melanin concentration is higher in birthmarks and melanomas [14,15]. Figure 2 shows the absorption spectrum of melanin [13].

Haemoglobin attached to red blood cells serves for oxygen transport in human body. Oxy-haemoglobin carries oxygen from lungs to other organs, giving blood its red colour. Structural differences between oxy-haemoglobin and deoxyhaemoglobin result in differences in absorption spectrum (see Fig. 2) in the spectral range from $500 \mathrm{~nm}$ to $600 \mathrm{~nm}[16]$.

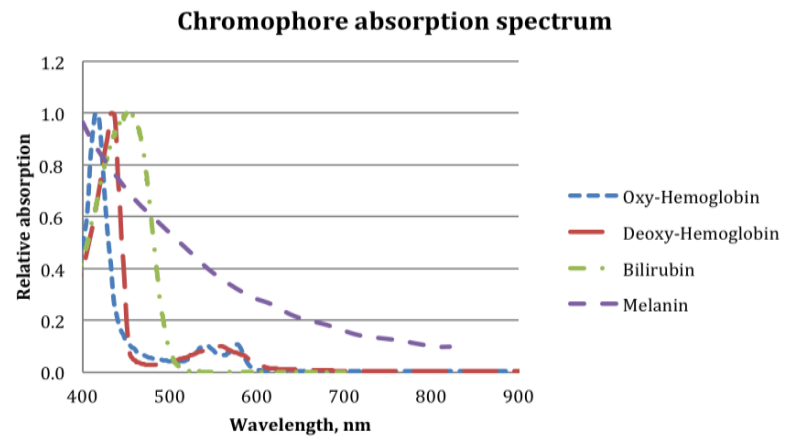

Fig.2. Chromophore absorption spectra [13].

\section{EXPERIMENTAL}

In this research, a phantom of skin was developed and its optical properties (absorption and scattering) were analyzed. Different phantoms were examined and compared in order to find the most suitable. In this article, the most promising ones will be discussed. The main focus is on biologically equivalent substances. For mimicking the skin medium and layered structure, a fibrin matrix with epidermal and dermal cell inclusion was used. Synthesized bilirubin, red blood cells and nigrosin were used as absorbers. In order to analyze the spectral properties of developed phantoms, a computer-aided multi-spectral imaging system Nuance 2.4 (Cambridge Research \& Instrumentation, Inc., USA) was employed (Fig.3). The data obtained are diffuse reflectance images of skin phantom in the visible and near-infrared spectral range from $450 \mathrm{~nm}$ to $900 \mathrm{~nm}$ with a step of $10 \mathrm{~nm}$, thus making it an image sequence. A light source of three halogen lamps was taken for illumination. 
As seen in Fig.3, in front of the light source a linear polarizer is set. The cross-polarization effect is used for reducing the instantly reflected light from the surface of the phantom. The linear polarizer is orthogonal to the built-in polarizer (Nuance 2.4) placed underneath a liquid-crystal tuneable interface filter [17].

The spectral imaging device Nuance 2.4 consists of tuneable interference filters for spectral scanning. The light interaction with the medium differs depending on the wavelength of the light source [18]. To obtain the image sequence, for each image at a particular wavelength the exposure time was from $1 \mathrm{~ms}$ to $6 \mathrm{~ms}$.

The computer program Nuance 2.4 was set up with the parameters: $4 \times 4$ pixel binning and resolution of $0.15 \mathrm{~mm} /$ pixel. The total resolution of the obtained image was $348 \times 256$ pixels. As reference measurement, the spectral image of a thick piece of white paper was taken. The surface area of examined phantoms was $1.886 \mathrm{~cm}^{2}$, the distance between the sample and the camera $-17 \mathrm{~cm}$, and the time used for acquisition of one image sequence $-\sim 20 \mathrm{~s}$.

In the Nuance 2.4 software it is possible to obtain the average spectrum of an area of the image that can be chosen by the user. For each image sequence, an average area spectrum was obtained and analyzed using Microsoft Office Excel 2007 [19].

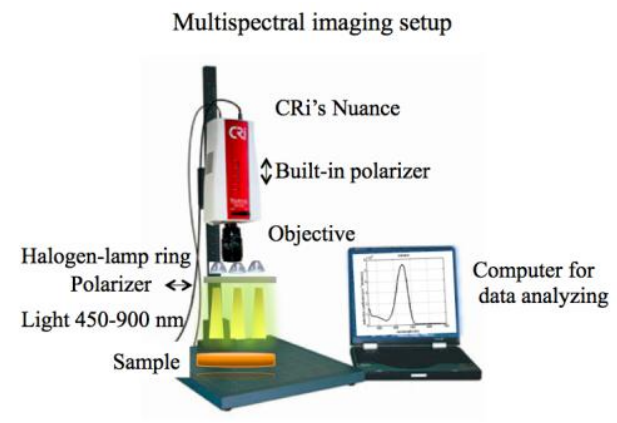

Fig.3. Experimental setup.

A fibrin matrix for skin phantoms can be prepared by mixing $0.47 \mathrm{ml}$ blood plasma ( $47 \%$ of the solution), $0.4 \mathrm{ml} 0.9 \%$ sodium chloride ( $40 \%$ of the solution), $0.8 \mu \mathrm{l}$ tranexamic acid $(0.8 \mathrm{mg} / \mathrm{ml})$, and $89.4 \mu \mathrm{l}$ calcium gluconate $(8.94 \mathrm{mg} / \mathrm{ml})$. To polymerize the solution it was held for one hour in a cell incubator (temperature $37^{\circ} \mathrm{C}, \mathrm{CO}_{2}$ concentration $5 \%$ ). To make a complete phantom, the next step was making the same solution and adding dermal cells $\left(180-270 \cdot 10^{3}\right.$ cells, fibroblast cell line 7Dp3). Afterwards, to polymerize the solution it was held in a cell incubator for $10 \mathrm{~min}$. The last step was adding epidermal cells $\left(270 \cdot 10^{3}\right.$ cells, keratinocyte cell line 8Ep1)) and a cell culture medium (fetal bovine serum). To grow epidermal and dermal cells, the fibrin matrixes with cellular inclusions were held in a cell incubator for at least two weeks [20].

To investigate the absorption spectrum dependence on admixtures of absorbents, a fibrin matrix without cellular inclusions was made. In these experiments, for rapid evaluation of the determined chromophore phantom, the fibrin matrix was used as a medium for skin phantom since only one day is needed to make it ready for measurements instead of two weeks - i.e. the time for making 
a complete skin phantom with dermal and epidermal cells. The fibrin matrix can be used instead of the full skin phantom since absorption of both media is low comparing with that of synthesized bilirubin, nigrosin and haemoglobin. To examine the calibration potential of the proposed skin phantom, 72 samples were made: each 24 contain the same absorbent in different concentrations. The synthesized bilirubin concentrations were 0.01 to $2.00 \mathrm{mg} / \mathrm{ml}$, the nigrosin concentrations -1.5 to $312.8 \mu \mathrm{g} / \mathrm{ml}$, and the red blood cell concentrations -0.2 to $42.4 \mathrm{mg} / \mathrm{ml}$. For further processing of the data, only 10 of 24 of the nigrosin samples could be used, while 14 were oversaturated. Increasing the nigrosin concentration in the sample makes the sample dark purple, and most of the illumination light becomes absorbed instead of being diffuse-reflected.

For this study, a layered structure was made as consisting of the bottom layer of the fibrin matrix (volume: $0.3 \mathrm{ml}$, corresponding thickness: $0.16 \mathrm{~cm}$ ), the absorbent included in different concentrations, and the upper layer of fibrin matrix (volume: $0.3 \mathrm{ml}$, corresponding thickness $0.16 \mathrm{~cm}$ ). In Fig.4 the visual appearance of samples is presented. The prepared sample maintains its optical properties for up to one week. Afterwards, the biological structures break down and the spectrum of the sample changes.

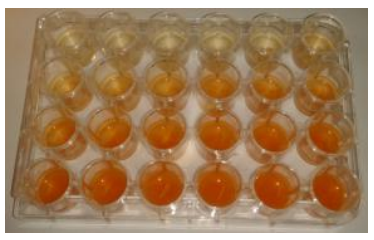

Fig.4. The sample of a fibrin matrix with bilirubin in different concentrations.

\section{RESULTS AND DISCUSSION}

With the developed skin phantom, it was possible to imitate the spectrum of skin (see Fig. 5). The absorber's concentration in the sample (Fig. 6) is high enough to imitate the determined chromophore absorption spectrum. Figures 7, 8 , and 9 illustrate the relative intensity of the absorption spectrum in dependence on the concentration of absorbent in the sample. It is seen that the intensity is changing linearly with the concentration of chromophore phantom in the fibrin matrix (the data are approximated).

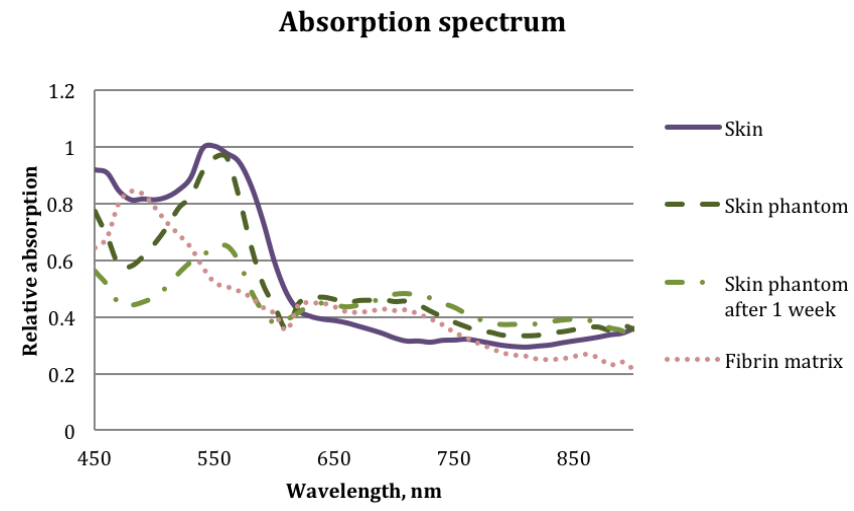

Fig.5. Absorption spectra of human skin and skin phantom. 
Absorption spectrum of absorbents

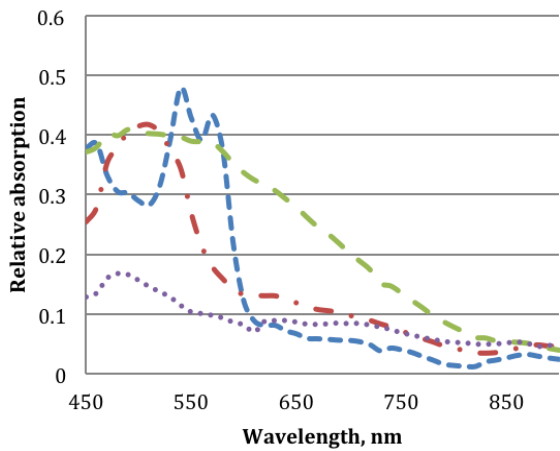

- - Erythrocytes

- Synthesized bilirubin

- Nigrosin

Fig.6. Absorption

..... Fibrin matrix spectra of absorbents.

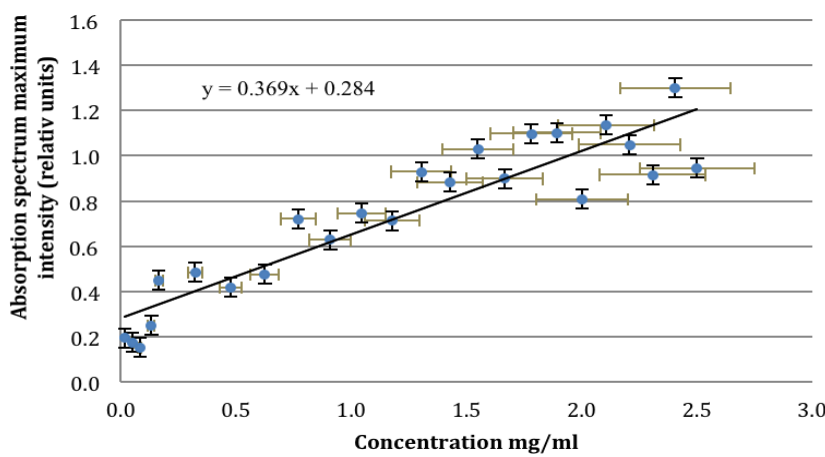

Fig.7. Absorption band intensity $v s$. bilirubin concentration.

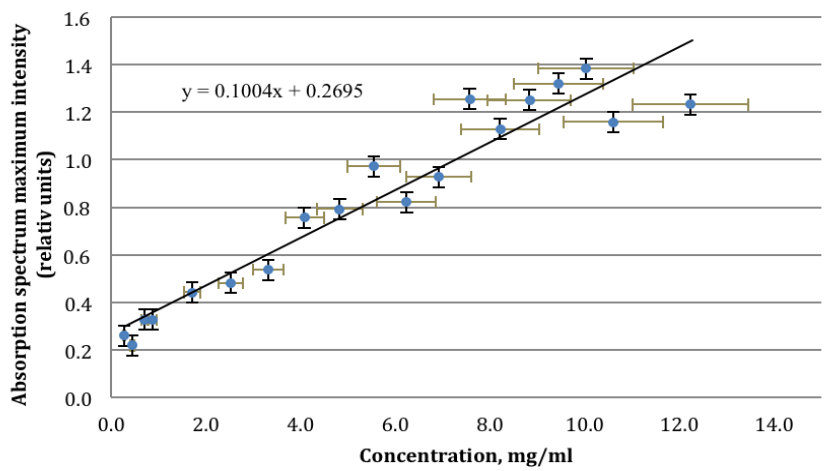

Fig.8. Absorption band intensity $v s$. red blood cell concentration.

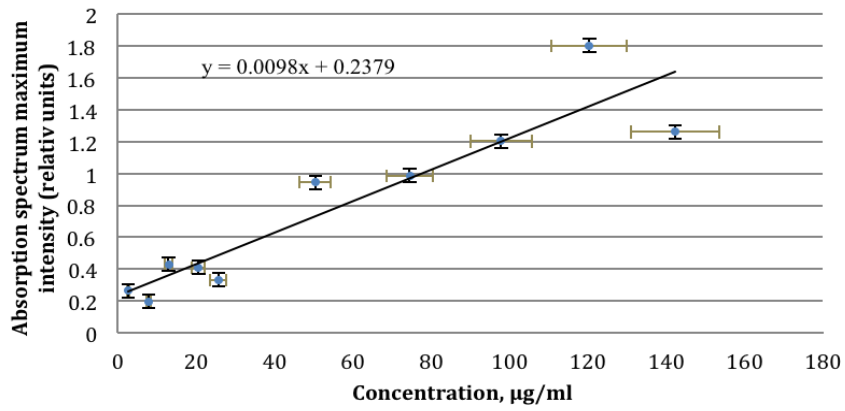

Fig.9. Absorption band intensity $v s$. nigrosin concentration. 


\section{CONCLUSIONS}

The results show that synthesized bilirubin, haemoglobin, and nigrosin can be used in biological phantoms as chemical substances for simulation of skin chromophores. In skin phantoms as a medium that mimicks the diffuse nature of human skin a fibrin matrix can be used in combination with dermal and epidermal cells. Besides, the proposed skin phantom is applicable to the calibration of multispectral imaging devices.

The proposed skin phantom is appropriate as a precisely characterized validation tool. However, this cannot be used for inter-laboratory comparison and standardization because of its instability in time.

\section{REFERENCES}

1. Xu, R., Xu, J., Qin, R., Huang, J. (2010) Developing multifunctional tissue simulating phantoms for quantitative biomedical optical imaging. Proc.SPIE, 7567, 75670K

2. Fujimoto, J. G., \& Farkas, G. L. (2009). Biomedical Optical Imaging. Quantitative Absorption and Scattering Spectra in Thick Tissues Using Broadband Diffuse Optical Spectroscopy, (12), 330-356.

3. Pogue, B. W., \& Patterson, M. S. (2006). Review of tissue simulating phantoms for optical spectroscopy, imaging and dosimetry. Journal of Biomedical Optics, 11(4), 041102.

4. Ayers, F., Grant, A., Kuo, D., Cuccia, D. J., \& Durkin, A. J. (2008). Fabrication and characterization of silicone-based tissue phantoms with tunable optical properties in the visible and near infrared domain. Proc. SPIE, 6870,687007.

5. Di Ninni, P. Martelli, F., \& Zaccanti, G. (2011). Toward a reference standard for tissue phantoms. Proc. SPIE, 7906, 79060M.

6. Ankri, R., Fixler, D., \& Taitelbaum, H. (2011). Reflected light intensity profile of twolayer tissues: phantom experiments. Proc. SPIE, 16, 085001.

7. Pravdin, A. B., Utz, S.U., \& Kochubey, V.I. (1995). Physical modeling of human skin optical properties using milk and erythrocytes mixtures. Proc. SPIE, 2627, 221-226.

8. Bergmanna, T., Beer, S., Maeder, U., Burg, J.M., Schlupp, P., Schmidts, T., Runkel, F., \& Fiebich, M. (2011). Development of a skin phantom of the epidermis and evaluation by using fluorescence techniques. Proc. SPIE 7906E,18B.

9. Saager, R.B., Kondru, C., Au, K., Sry, K., Ayers, F., \& Durkin, A.J. (2010). Multilayer silicone phantoms for the evaluation of quantitative optical techniques in skin imaging. Proc. SPIE, 7567, 756706-1.

10. Vo-Dinh, T. (2003). Biomedical Photonics Handbook. Photonics and Tissue Optics, (1).

11. Vo-Dinh, T. (2003). Biomedical Photonics Handbook. Optical Properties of Tissue, (2).

12. Sherwood, L. (2007). Human Physiology From Cells to Systems $\left(6^{\text {th }}\right.$ ed-n). Digestive System, (16), 609.

13. Natural Phenomena Simulation Group, University of Waterloo: available at: [25.04.2013.] http://www.npsg.uwaterloo.ca/data/skin.php

14. Saknīte, I. (2012). Ādas hromoforu sadalījuma noteikšana ādā ar multispektrālo attēlošanu: maǵistradarbs, LU Fizikas un matemātikas fakultāte (Latvia).

15. Sherwood, L. (2007). Human Physiology from Cells to Systems $\left(6^{\text {th }}\right.$ ed-n). Body Defenses, (12), p.443.

16. Sherwood, L. (2007). Human Physiology from Cells to Systems $\left(6^{\text {th }}\right.$ ed-n). The Blood, (11), p. 387. 
17. Demos, S.G., \& Alfano, R.R. (1997). Optical polarization imaging. Applied Optics, 36 (1), $150-155$.

18. VariSpec Brochure. Research and Instrumentation, Inc., available at: [18.02.2010.]. http://www.cri-inc.com/support/components.asp.

19. Natural Phenomena Simulation Group, University of Waterloo, available at: [25.04.2013.] http://www.npsg.uwaterloo.ca/data/skin.php

20. Negri, S., Federici, G., Farinato, S., Fila, C. (2009). Human plasma as dermal scaffold for the generation of a completely autologous bioengineered skin. Journal of Clinical Rehabilitative Tissue Engineering Research, 13.

\title{
ĀDAS HROMOFORU IN VITRO KARTĒŠANAS MAKETU IZVEIDE UN EKSPERIMENTĀLA IZPĒTE
}

\author{
A. Silapētere, I. Saknīte, J. Spīgulis
}

Kopsavilkums

Mūsdienās multispektrālās attēlošanas iekārtas izmanto ādas parametru un fiziologisko procesu aprakstīšanai gan pētniecības, gan diagnostikas nolūkiem. Iekārtu darbības uzlabošanai ir nepieciešams labāk saprast gaismas mijiedarbību ar audiem, kā arī veikt šo iekārtu kalibrēšanu ar ādas maketu. Redzamā un tuvā infrasarkanā optiskā diapazona spektroskopijā ir svarīgi ādas maketi, kas simulē audu slāņaino struktūru un k̦īmiskās īpašības, kā arī maketi, kas ir biologíski līdzvērtīgi. Šajā pêtījumā tika izveidots ādas makets no biolog̣iskām un ķīmiski sintezētām struktūrām.

Ādas maketa izveidei tika izmantota fibrīna matrica ar dermālo un epidermālo šūnu piejaukumu, lai imitētu ādas slāņaino struktūru. Fibrīna matrica tiek veidota no $0,47 \mathrm{ml}$ asins plazmas, $0,4 \mathrm{ml}$ fizioloǵiskā šşīduma, $0,8 \mu \mathrm{l}$ treneksāmskābes un $89,4 \mu \mathrm{l}$ kalcija glukanāta. Izveidoto matricu ievieto šūnu inkubatorā, lai tā polimerizētos. Nākošais slānis tiek veidots ar dermālo šūnu piejaukumu (180-270* $10^{3}$ šūnas), un pēdējais fibrīna matriksa slānis tiek veidots ar epidermālo šūnu piejaukumu $\left(270^{-10^{3}}\right.$ šūnas) un šūnu augšanu veicinošu serumu (FBS). Šūnu kultivēšanai nepieciešamas vismaz divas nedēḷas. Šajā slāņainajā struktūrā ir iespējams pievienot ādas hromoforu simulējošus iekḷāvumus. Optiskajā diapazonā no 450-900 nm ādas hromoforas, kurām ir visizteiktākais spektrs, ir bilirubīns, melanīns un hemoglobīns. Lai simulētu ādas hromoforu spektrālās īpašības, tika izmantots sintezēts bilirubīns, eritrocītu masa un nigrozīns.

Lai izpētîtu šī maketa iekārtu kalibrēšanas potenciālu, tika izveidoti 76 paraugi, kur katros 24 paraugos bija pievienots viens no absorbentiem ar dažādām koncentrācijām. Pilna ādas maketa audzēšanai nepieciešamas divas nedēḷas, lai ātrāk tiktu iegūti pirmie rezultāti tika veidoti maketi bez dermālo un epidermālo šūnu piejaukuma. Fibrīna matricas un ādas imitējošā maketa absorbcijas spējas ir mazas salīdzinājumā ar hromoforu absorbcijas spējām. Lai novērtētu maketu, kas paredzēti konkrētu hromoforu spektrālo īpašību imitēšanai, iespējams veikt eksperimentus ar fibrīna matricu, kuras izveidošanai ir nepieciešama viena diena. Sintezētā bilirubīna koncentrācijas tika mainītas robežās no $0,01-2,00 \mathrm{mg} / \mathrm{ml}$, melanīna optisko īpašību simulējošās vielas nigrozīna koncentrācija tika mainīta no $1,5-312,8 \mu \mathrm{g} / \mathrm{ml}$, eritrocītu masas koncentrācija mainījās no $0,2-42,4 \mathrm{mg} / \mathrm{ml}$. 
Mērījumi tika veikti, izmantojot multispektrālās attēlošanas iekārtu Cri Nuance 2.4. (Cambridge Research \& Instrumentation, Inc., Amerikas Savienotās Valstis). Absorbcijas spektrs tika apstrādāts, izmantojot Microsoft Office Excel 2007.

Iegūtajos rezultātos ir iespējams redzēt, ka piedāvātais ādas makets spēj simulēt ādas optiskās īpašības. Izmantotie absorbenti - sintezētais bilirubīns, nigrozīns un eritrocītu masa - spēj simulēt ādas hromoforu spektrālās īpašības. Palielinot absorbentu koncentrāciju paraugā, palielinās absorbcijas spektra maksimālā intensitāte. Izveidotais ādas makets varētu būt izmantojams iekārtu kalibrēšanai, taču šis makets nav piemērots starplaboratoriju iekārtu salīdzināšanai, jo tas nav stabils laikā.

17.05 .2014 